\title{
Modeling of Municipal Drainage and Urban Channel Flooding in Coastal City in the South of China
}

\author{
Xiyan Ren*, Demiao Yu \\ China Academy Urban Planning \& Design, Beijing 100044, China \\ *E-mail: renxiyan@126.com \\ Yongjun Ruan \\ Municipal Government of Beihai City, Beihai 536000, China \\ Guo Yu \\ Danish Hydraulic Institute, Shanghai 200120, China \\ Received 23 February 2015 \\ Accepted 25 April 2015
}

\begin{abstract}
A numerical model has been formatted including ocean, rain drainage, urban channels, and pumps by the software MIKE FLOOD which coupling MIKE URBAN, MIKE 11 and MIKE 21. The different scenarios have been simulated. The flooding warning water level of the urban channel is low to the spring tide height, when the precipitation in 30 years facing the ocean tide in 5 years, the rain flooding in some areas should be stored in the urban channel, waiting for the ocean tide height decrease, then discharge the rain flood. Several conclusions have been drawn as followed: (1) In China, the average impervious surface in the urban area is usually about $55 \%$ to $70 \%$, in the commercial central area, the impervious surface is usually about $75 \%-90 \%$, the impervious surface in Beihai urban area is higher than the average level in China, because the density of the constructs is too high, the land use should be changed and the Sponge City should be constructed, these measures will help to release the urban flooding problem. (2) To carryout low impact development facilities and construct urban flooding storage, drainage system both very important in coastal area, especially in typhoon area. (3)Compare two pipe and channel plans, the results show that the water logging of initial plan was heavy, and the water logging of optimization plan is relieved.
\end{abstract}

Keywords: Urban storm, Rain flooding, Sponge city, Modeling, coastal

\section{Introduction}

It is well known that the PRC has been a rapid urbanization process since1978. The urbanization rate increased from $17.0 \%$ to more than $53 \%$ up to now and is expected to reach $65 \%-70 \%$ in the next 20 years. Alongside rapid urbanization, the PRC faces challenges of insufficient water resources, water pollution, and frequent flooding disasters, especially the urban flooding disaster. Up to now, over 137 out of 656 cities suffer from waterlogging in varying degrees (SichengZhu et al., 2011), while urban flooding is caused by the uneven distribution of precipitation in time and space and the disappearance of flood plains, especially in the pluvial, coastal area. In coastal area in China, over $80 \%$ area face to the typhoon threats, and the intensive precipitation in the urban area will cause waterlogging, even bring the disaster.

Beihai City is located in Guangxi Zhuang Autonomous Region which is a developing coastal urban area on the North Bay of the South Seain China. Beihai City is located in the south of the Guangxi Zhuang Autonomous Region, and west to the Guangdong Province (Figure 1). The land area is about 3337 square kilo-meters and the planning urban area will be145 square kilo-meters. Beihai City is one of the 
14 initial Coastal open cities in China.Beihai City is suffered with the typhoon every year, and the typhoon more than 10 typhoons occurred 6 times interval 10 years. So Beihai was suffered with the urban flooding cause by the heavy rainfall. The data of precipitation in Beihai City was analyzed and the land use changed was analyzed in the city master plan stage. Because of the urban terrain elevation is very low and plain, the coastal location and the intensive precipitation, the urban flooding, channel flooding and ocean tide impact are related and will cause a very serious urban flooding problem. How to deal with the problem which storm facing to the spring tide by the urban rain drainage in the future? To construct a suitable urban channel system, a storage system and a drainage system, so as to ensure the rain flooding discharge rapidly by the drainage and urban channel is a very important key to guarantee the city safe.
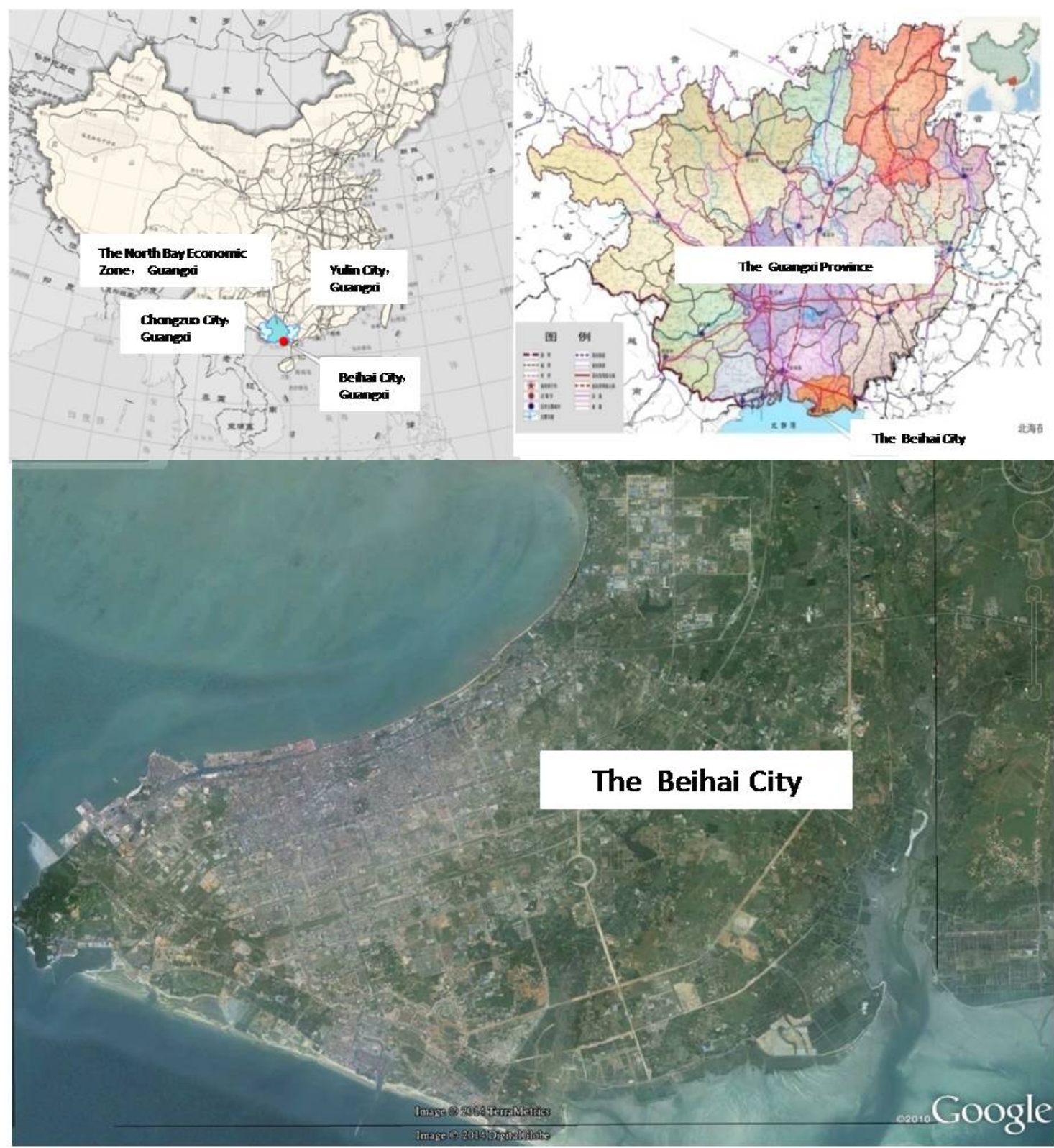

Fig1. The Location and the Status of Beihai City in Guangxi Zhuang Autonomous Region 
With the development of the Urban Drainage Modelling (UDM) technology, a lot of researchers use numerical model based on GIS to simulate the process of urban flooding and compare different scenario results, so as to find the best storm management plan. BerislavTomic and Ole Mark (2004)use MOUSE simulated the urban flooding at Playa de Gandia which is located in the Valencia province in Spain. They found that the complex hydrological- hydraulic mechanisms can be encapsulated into the model, and the results can be easily understandable animated. Then the complex urban flooding process can be simulated by the numerical model based on GIS, and the results of every pipe and the water logging on road also can be identified. ChusitApirumanekul and Ole Mark (2004)use MOUSE and Mike 11 to simulate the urban flooding in Dhaka city in Bangladesh. They found that a hydrodynamic model built in two layers describes both flows in pipe and street network can show us more information of urban flooding, the flooding inundation map can be carried out by GIS, and the results can be easily understood. Jonathan Parkinson and Ole Mark(2004) finished a lot of works in urban flooding, they research the urbanization and the urban hydrology changes. They also do some researches about the relation of climate changes and the urban flooding and they provide an introduction to ecological approaches to urban drainage system design. They concerned about the social and economic impacts of the urban flooding, and try to find a method to appraise the flooding risk of the urban flooding.

A lot of specialists research the urban flooding and urban water logging in China from the 1950s. And a series of computable formulation of storm intensity covers about 200 cities were formed by these research results. And these formulations were the main tools for drainage system plan and design. Many researchers in China analyse the urban flooding from different aspects. Yue-Zhang (2010)analyse the main reasons caused the urban flooding, and provide several measures to strength rain water management. SichengZhu and Xiyan-Ren (2011) analyse the recent water logging in several cities in China, and show us the reasons caused water logging from the several aspects such as urban plan, engineer technical, management, etc. In recent years with the development of the numerical model based on GIS, many researchers and engineers also use the numerical model to research urban flooding, main focus on the SWMM, InfoWorks CS, and MIKEFLOOD. Jun-Liu (2006) simulate the urban channel drainage in urban area in Shanghai city by using SWMM model. Hongtao-Ma and XiaoxinZhang (2008) constructed the MIKE Flood model, and simulated Olympic garden area urban flooding, compare different scenario plan.Xiaotao-Cheng (2009) discussed the relation of the urbanization and changes of flood control situation in the coastal regions in China, and introduced the theory and practice of flood risk management. The flood risk and simulation case studies including Shen Zhen city, Guang Zhou city and Tianjin city also were discussed. Bo-Huang et al. (2010) discussed flood risk management in the deltas of Yellow River, Rhine River and Mississippi River. The relation among the storm, the tide and the flood in the coastal area was discussed and the impacts of the hurricane Katrina were introduced.

In this article several results of an on-going project about Beihai City urban channel, drainage system and urban flooding modelling will be showed. A complex hydrological- hydraulic model including the tide of the sea, a slope runoff from the rain, a pipe flow and an urban channel flow was be constructed by using MIKE FLOOD which coupled with MIKE URBAN, MIKE 11 and MIKE 21. From the whole model we know that the flooding warning water level of the urban channel is low to the spring tide height, so when the precipitation in 30 years facing the ocean tide in 5 years, the rain flooding should be stored partly in the urban channel and the storage facilities, waiting for the ocean tide height decrease, then discharge the rain flooding to the sea. From the simulated results of different scenarios of the rain intensity, tide level, the urban flooding problem was indentified in several parts of the city. And then the urban pipe, urban channel plans be changed, the pump operation process be regulated, then the water logging can be relieved.

\section{Methodology}

\subsection{Storm intensity computation formulation}

The storm intensity computation formulation method is very popular in China when the rain drainage pipe system is designed. The formulation is formed based on long term precipitation monitoring and the statistic data of runoff from the ground and in the pipe experienced parameter. Because the monitor data was not enough 
before, so the storm intensity computation formulation was formed by using Multi Sample Method. In recent years, the monitor data of precipitation has been last for more than 30 years, so many scholars start to revise the storm intensity computation formulation using The annual maximum value method supported by the Meteorological Department. The storm intensity computation formulation of Beihai using Multi Sample Methodis adopted for this case runoff computation to calibrate and validate to the MIKE URBAN result each other.

$$
q=\frac{1625 \times(1+0.437 \times \lg P)}{(t+4)^{0.57}}
$$

Q_ Design storm intensity (L/ha.s);

$\mathrm{P}$ - Design return period (a);

$\mathrm{t}$-Runoff time (min), $\mathrm{t}=\mathrm{t} 1+\mathrm{mt} 2$;

$\mathrm{t} 1$ - Ground runoff time, $\mathrm{t} 1=10 \mathrm{mins}$;

t2- Pipe runoff time;

$\mathrm{m}$ - Delay time, pipe, $\mathrm{m}=2$, channel, $\mathrm{m}=1.2$.

\subsection{MIKE FLOOD}

\subsubsection{MIKE URBAN}

Saint Venant Equations - General

Conservation of Mass (continuity equation)

$$
\frac{\partial \mathrm{Q}}{\partial \mathrm{x}}+\frac{\partial \mathrm{A}}{\partial \mathrm{t}}=0
$$

Conservation of Momentum (momentum equation)

$$
\frac{\partial \mathrm{Q}}{\partial \mathrm{t}}+\frac{\partial\left(\alpha \frac{\mathrm{Q}^{2}}{\mathrm{~A}}\right)}{\partial \mathrm{x}}+\mathrm{gA} \frac{\partial \mathrm{y}}{\partial \mathrm{x}}+\mathrm{gAI}_{\mathrm{f}}=\mathrm{gAI}_{0}
$$

where:

$\mathrm{Q}=$ discharge, [m3s-1]

$\mathrm{A}=$ flow area, [m2]

$\mathrm{y}=$ flow depth, [m]

$\mathrm{g}=$ acceleration of gravity, [ms-2]

$\mathrm{x}=$ distance in the flow direction, $[\mathrm{m}]$

$\mathrm{t}=$ time, $[\mathrm{s}]$

$\alpha=$ velocity distribution coefficient

I0 = bottom slope

If $=$ friction slope

\subsubsection{MIKE 11}

Saint Venant Equations - General

Conservation of mass:

$$
\frac{\partial(\rho H b)}{\partial t}=-\frac{\partial(\rho H b u)}{\partial x}
$$

Conservation of momentum:

$$
\frac{\partial(\rho H b u)}{\partial t}=-\frac{\partial\left(\alpha^{\prime} \rho H b u^{2}+\frac{1}{2} \rho g b H^{2}\right)}{\partial x}
$$

where, $\rho$ is the density, $\mathrm{H}$ the depth, $\mathrm{b}$ the width, the average velocityalong the vertical and $\alpha$ ' the vertical velocity distribution coefficient.

\subsubsection{MIKE 21}

$$
\frac{\partial \delta}{\partial t}+\frac{\partial p}{\partial x}+\frac{\partial q}{\partial y}=\frac{\partial d}{\partial t}
$$

$\frac{\partial p}{\partial t}+\frac{\partial}{\partial x}\left(\frac{p^{2}}{h}\right)+\frac{\partial}{\partial y}\left(\frac{p q}{h}\right)+g h \frac{\partial \delta}{\partial x}+\frac{g p \sqrt{p^{2}+q^{2}}}{C^{2}+h^{2}}-$

$\frac{1}{\rho_{w}}\left[\frac{\partial}{\partial x}\left(h \tau_{x x}\right)+\frac{\partial}{\partial y}\left(h \tau_{x y}\right)\right]-\omega_{q}-f V V_{x}+\frac{h}{\rho_{w}} \frac{\partial}{\partial x}\left(p_{a}\right)=0$

$\frac{\partial q}{\partial t}+\frac{\partial}{\partial y}\left(\frac{q^{2}}{h}\right)+\frac{\partial}{\partial x}\left(\frac{p q}{h}\right)+g h \frac{\partial \delta}{\partial y}+\frac{g p \sqrt{p^{2}+q^{2}}}{c^{2}+h^{2}}-$

$\frac{1}{\rho_{w}}\left[\frac{\partial}{\partial y}\left(h \tau_{y y}\right)+\frac{\partial}{\partial x}\left(h \tau_{x y}\right)\right]+\omega_{p}-f V V_{y}+\frac{h}{\rho_{w}} \frac{\partial}{\partial y}\left(p_{a}\right)=0$

The following symbols are used in the equations:

$$
\begin{array}{ll}
\mathrm{h}(\mathrm{x}, \mathrm{y}, \mathrm{t}) & \text { water depth }(=\delta \text {-d, } \mathrm{m}) \\
\mathrm{d}(\mathrm{x}, \mathrm{y}, \mathrm{t}) & \text { time varying water depth }(\mathrm{m}) \\
\delta(\mathrm{x}, \mathrm{y}, \mathrm{t}) & \text { surface elevation }(\mathrm{m}) \\
\mathrm{p}, \mathrm{q}(\mathrm{x}, \mathrm{y}, \mathrm{t}) & \text { flux densities in } \\
\text { directions }(\mathrm{m} 3 / \mathrm{s} / \mathrm{m})=(\mathrm{uh}, \mathrm{vh}) ;(\mathrm{u}, \mathrm{v})=\text { depth } \\
\text { velocities in } \mathrm{x} \text { - and y-directions } \\
\mathrm{C}(\mathrm{x}, \mathrm{y}) & \text { Chezy resistance }\left(\mathrm{m}^{1 / 2} / \mathrm{s}\right) \\
\mathrm{g} & \text { acceleration due to gravity }\left(\mathrm{m} / \mathrm{s}^{2}\right) \\
\mathrm{f}(\mathrm{V}) & \text { wind friction factor }
\end{array}
$$$$
\mathrm{p}, \mathrm{q}(\mathrm{x}, \mathrm{y}, \mathrm{t}) \text { flux densities in } \mathrm{x} \text {-andy- }
$$
directions $(\mathrm{m} 3 / \mathrm{s} / \mathrm{m})=(\mathrm{uh}, \mathrm{vh}) ;(\mathrm{u}, \mathrm{v})=$ depth averaged

$\mathrm{V}, \mathrm{Vx}, \mathrm{Vy}(\mathrm{x}, \mathrm{y}, \mathrm{t}) \quad$ wind speed and components in $\mathrm{x}$ - and $\mathrm{y}$-directions $(\mathrm{m} / \mathrm{s})$

$\omega(\mathrm{x}, \mathrm{y}) \quad$ Coriolis parameter, latitude dependent $\left(\mathrm{s}^{-1}\right)$

$\mathrm{Pa}(\mathrm{x}, \mathrm{y}, \mathrm{t}) \quad$ atmospheric pressure $\left(\mathrm{kg} / \mathrm{m} / \mathrm{s}^{2}\right)$

pw density of water $\left(\mathrm{kg} / \mathrm{m}^{3}\right)$

$\mathrm{x}, \mathrm{y} \quad$ space coordinates $(\mathrm{m})$

$\mathrm{t} \quad$ time (s)

$\tau \mathrm{xx}, \tau \mathrm{xy}, \tau \mathrm{yy}$ components of effective shear stress

\subsubsection{MIKE FLOOD}

MIKE 11 requires a water level boundary from MIKE 21 at time step $\mathrm{n}+1$ in order to step from time step nto $n+1$. Therefore, MIKE 21 will always be one time step 
ahead of MIKE 11. Thus, in order to provide a discharge to MIKE 21 at time step $n+1 / 2$, a predictor may be applied in MIKE 11 toestimate the discharge $\mathrm{Q} n+1 / 2$. For the flexible mesh the standard link is designed is such a way that the linkage line is mapped onto one or more element faces. Thus from MIKE21's point of view, the link functions as a boundary condition. In return MIKE 21 transfers an average water level across the coupled element face which is then subsequently used in MIKE 11.

During computation, each internal structure is assigned a water level from the river and from the overland solver. These values are found by interpolating levels at existing calculation points onto the internal structures. Water levels are interpolated from the MIKE 21 cells and the MIKE $11 \mathrm{~h}$ points to the specific internal structure locations. The structure link takes the implicit terms describing momentum through a 3 point MIKE 11 branch and uses them to replace or modify the implicit terms describing momentum across the face of a MIKE 21 cell. In this way, the flow properties from one MIKE 21 cell to another are modified to represent a structure.

MIKE FLOOD is coupled with MIKE URBAN, MIKE 11 and MIKE 21, though it can simulated complex process including the precipitation, the runoff on the ground, the runoff in the pipe, the entrance from the pipe to the channel, the channel water situation, and the water logging caused by the urban flooding, this system can give us the urban flood dynamic results. Different scenarios including precipitation, rain drainage pipe system, urban channel, urban plan can be simulated rapidly.

\subsubsection{Beihai Model}

According the plans a simulated model was constructed by MIKE FLOOD. The Digital Elevation Model was formed by using topographic map which scale is $1: 10000$, and the land use and building information was revised by the investigation and mapping (Fig2). The computation bound focus on the planning construct area including the status and planning land. And the pipe information, the channel, the storage facilities, other information ware input in the MIKE FLOOD MODEL. So the computation model was formed(Fig3).

\section{Results and Discussion}

\subsection{The urbanization and precipitation runoff}

It is well known that the urban area extended affect the evaporation, and the infiltration, and the runoff. According the research of the relation among the land use, evaporation, infiltration and runoff, the result show us different imperious surface will affect the runoff. With the land cover of impervious surface added, the runoff will increase rapidly. When the impervious surface is low to $20 \%$ of the land use, the increase rate of the runoff is equal to the increase rate of impervious surface. When the impervious surface is low to $50 \%$ of the land use, the increase rate of the runoff is low to the increase rate of the impervious, but when the impervious surface is up to $50 \%$, the runoff will increase rapidly, and the increase rate is more than the increase rate of the impervious surface (Table1). In china, the average impervious surface in the whole urban area is usually about $55 \%$ to $70 \%$, in the commercial central area, down town area and the industrial area, the impervious surface is usually about 75\%-90\%.

The land use of the Beihai city was analysis by the situation mapping information, and the runoff of grass land is about $15 \%$, the runoff of water body is about $100 \%$, the runoff of road is about $85 \%$, the runoff from different residential area is about $65 \%$ to $85 \%$ (Table2). In recent years the Sponge City construction model has been popular in China. And 16 cities have been selected as the Sponge City construction demonstration area by the national government in the next 3 years. More than 30 cities will carry out the policies and the measurements to construct the Sponge City in next 3 years. The function (infiltration, lag, purification, using and reusing, drainage of the rain) of Sponge City is very strong. To construct Sponge City is useful to help release the problem of water safety, water resource and water environment. And the land use in the building area of the Sponge City will be fit to the $\mathrm{B}$ and $\mathrm{C}$ below table, so the runoff will be reduced $60 \%-80 \%$ by computation of the plan mapping scenario. According the land use of Beihai urban constructed area, the runoff number can be calculated by the remote image in different regions covered the constructed area and the runoff number of the plan region also can be calculated by the urban master plan. 

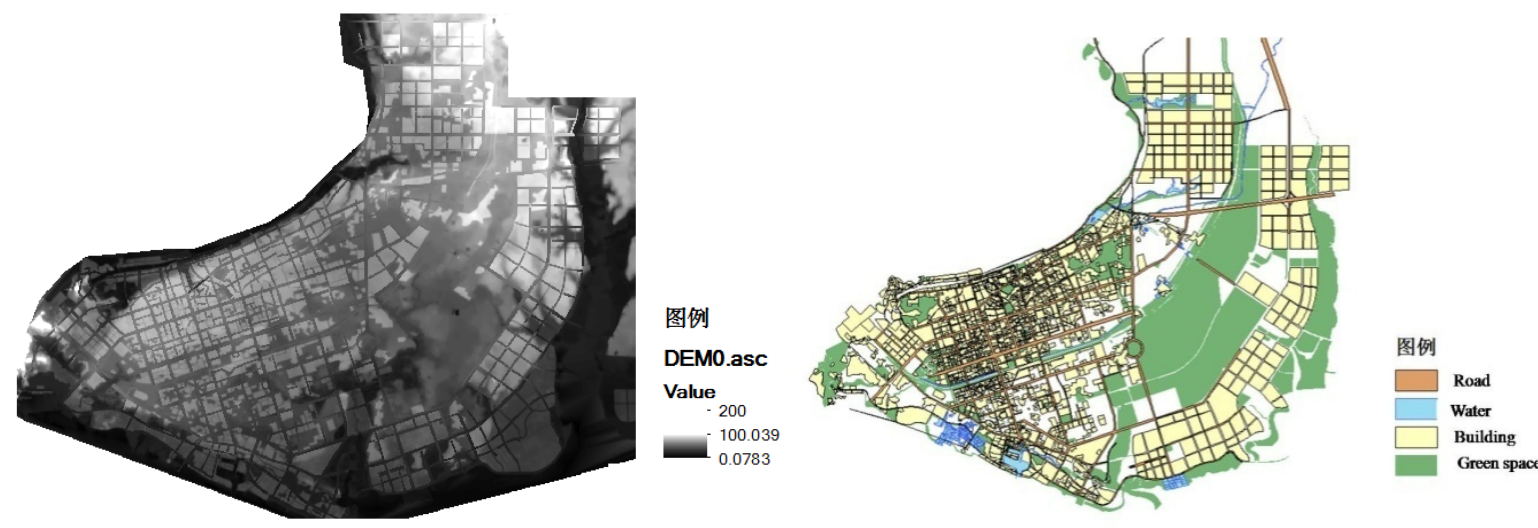

Fig2. The Digital Elevation Model of Beihaiurban area and the land use distribution map
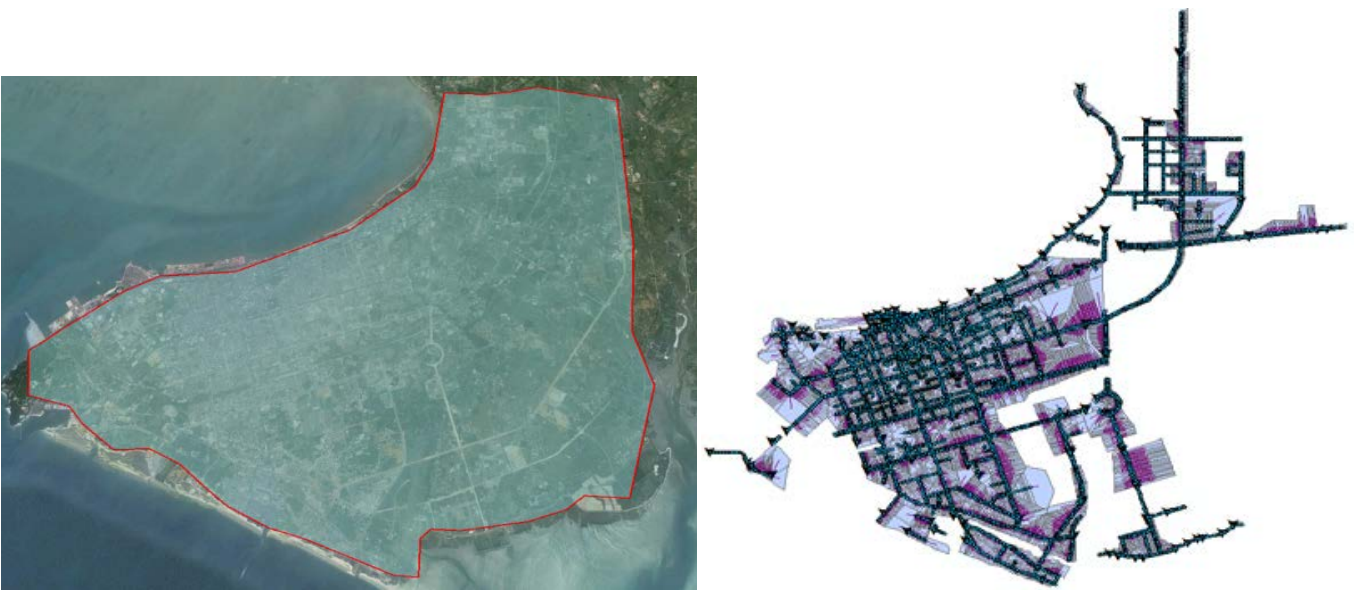

Fig3. The MIKE FLOOD Model of Beihai computation urban area

Table1.Different Runoff Percentage of Different Land Use.

\begin{tabular}{cccccc}
\hline & Land use & Evapotranspiration & Shallow infiltration & Deep infiltration & Runoff \\
\hline A & Nature Ground Cover & $40 \%$ & $25 \%$ & $25 \%$ & $10 \%$ \\
& & & & & $21 \%$ \\
B & $10-20 \%$ Impervious Surface & $38 \%$ & $21 \%$ & $15 \%$ & $30 \%$ \\
C & $35-50 \%$ Impervious Surface & $35 \%$ & $10 \%$ & $5 \%$ & $55 \%$ \\
D & $75-100 \%$ Impervious Surface & $30 \%$ & & \\
\hline
\end{tabular}

(Cite from Fig1)

Table 2 Different Runoff Percentage of Different Land Use.

\begin{tabular}{cccc}
\hline \multicolumn{3}{c}{ Land use in Beihai } & Runoff \\
\hline 1 & Nature land and Liyudi Garden & Nature Ground Cover & $10 \%$ \\
2 & City park and Grass land & 10-20\%Impervious Surface & $10 \%-20 \%$ \\
3 & Low density urban area & 35-50\%Impervious Surface & $40 \%-55 \%$ \\
4 & High density urban area & $75-100 \%$ Impervious Surface & $65 \%-75 \%$ \\
\hline
\end{tabular}



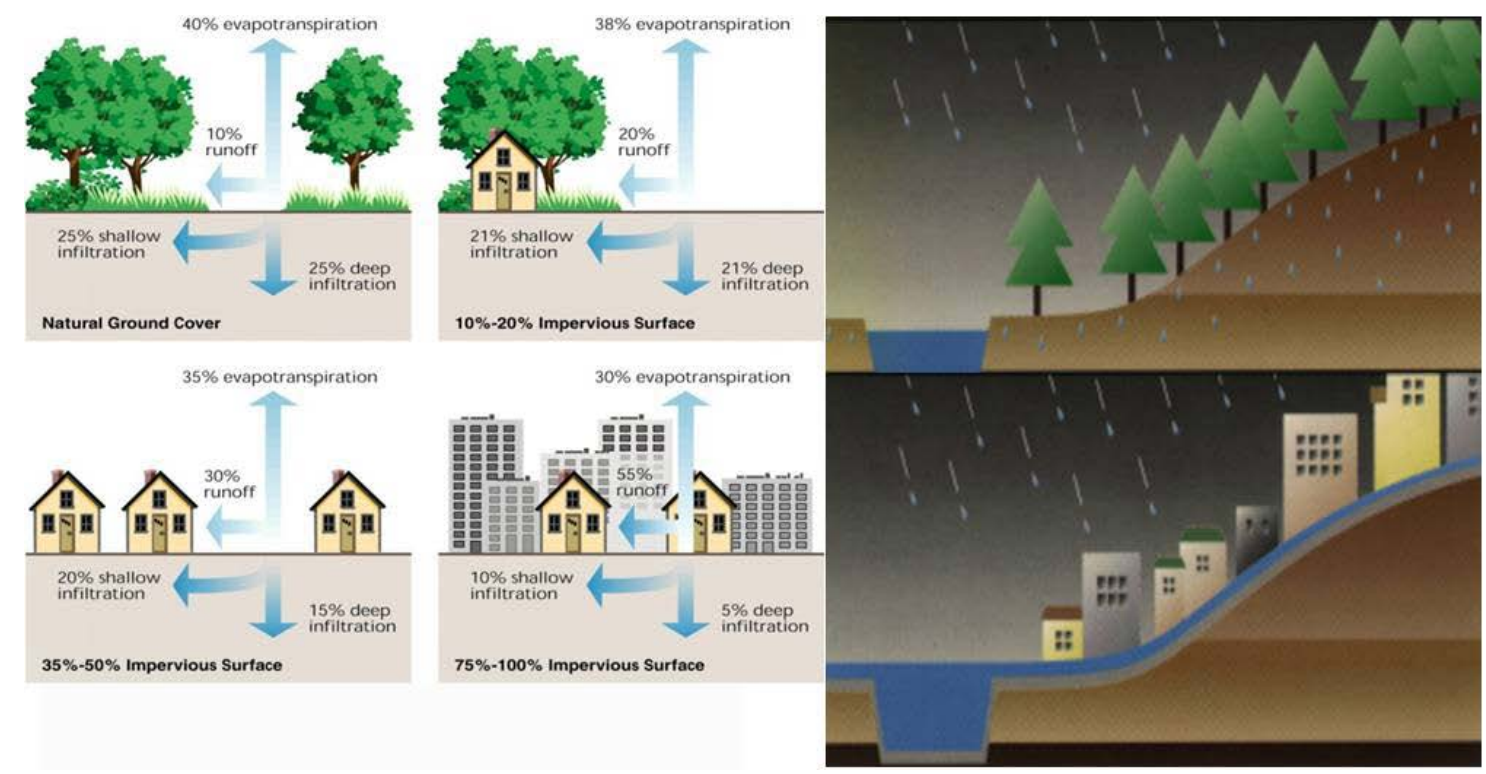

Fig.4 The Relation of Different Land Use and Runoff （Cite from DHI Report）

\subsection{The relationship of the precipitation and the tide}

According to the precipitation data analysis, the precipitation process was very different, some precipitation process last no more than last 24 hours, and some precipitation process last more than 72 hours. The 24 hours precipitation data (from 1956 to 2005) was selected to analyze by Pearson III curve fitting method. In this paper, two rainfall processes were analyzed, one is the precipitation of the super typhoon Rammasun, the other is the precipitation of the hungry ghost festival. The real precipitation of the super typhoon Rammasunis 185.3mmduring 24 hours and the real precipitation of the hungry ghost festival is 242.4 mmduring 24 hours. The 24 hours precipitation of the hungry ghost festival was almost equal to the 30 years reoccurrence design 24 hour precipitation. And the maximum 1 hour precipitation of the 24 hours precipitations $77.7 \mathrm{~mm}$, more than 5 years reoccurrence design 1 hour precipitation. The rain drainage pipe design storm return period or sometimes called precipitation probability can be computed by the meteorological data (Table 3-5).

The precipitation process of super typhoon Rammasun last 18 hours, and there were two peaks interval 1 hour. The first peak last 5 hours and the total precipitation is $54.8 \mathrm{~mm}$. The maximum precipitation during 1 hour is $16 \mathrm{~mm}$. The second peak last 6 hours and the total precipitation is $119.6 \mathrm{~mm}$. The maximum precipitation during 1 hour is $30.5 \mathrm{~mm}$. The first rainfall peak meet with a spring tide process, and the second rainfall peak meet with an ebb tide process, but the final 2 hours precipitation of the second peak were more than others in the whole rainfall process (Fig 5). The rainfall continued 13 hours, at the same time the precipitation process meets a small tide process. So the water logging in urban area was not heavy (Fig 6).

Table 3.Different Storm Return Period(Rain drainage pipe design) 60mins precipitation.

\begin{tabular}{ccc}
\hline Return Period & Probability & 60mins precipitation $(\mathrm{mm})$ \\
\hline 1 & $1 \%$ & 52 \\
3 & $33.3 \%$ & 65 \\
5 & $20 \%$ & 71 \\
\hline
\end{tabular}


Table 4.Precipitation with Tidal Level during the process of the super typhoon Rammasun

\begin{tabular}{ccc}
\hline Precipitation interval & Precipitation $60 \mathrm{mins}(\mathrm{mm})$ & Tidal Level $(\mathrm{m})$ \\
\hline 1 & 0.6 & -0.58 \\
2 & 0.4 & -0.63 \\
3 & 0.3 & -0.54 \\
4 & 5.7 & -0.34 \\
5 & 9.5 & -0.10 \\
6 & 13.3 & 0.12 \\
7 & 16 & 0.26 \\
8 & 10.3 & 0.31 \\
9 & 0 & 0.26 \\
10 & 1.1 & 0.14 \\
11 & 14.4 & 0.00 \\
12 & 15.9 & -0.16 \\
13 & 9.6 & -0.28 \\
14 & 19.8 & -0.32 \\
15 & 30.5 & -0.26 \\
16 & 29.4 & -0.11 \\
17 & 0.9 & 0.08 \\
18 & 7.6 & 0.24 \\
\hline
\end{tabular}

The precipitation process of the hungry ghost festival last 18 hours, and there were also two peaks interval 1 hour during 6th to 8th August, 2014. The first peak last 2 hours and the total precipitation is $34.6 \mathrm{~mm}$. The maximum precipitation during 1 hour is $18.4 \mathrm{~mm}$. The second peak last 4 hours and the total precipitation is $199.6 \mathrm{~mm}$. The maximum precipitation during 1 hour is $77.7 \mathrm{~mm}$. The two rainfall peak meet with a spring

tide process, and because the rainfall process is not so long, so the whole rainfall process cover the spring tide peak, especially the second rainfall peak meet with the spring tide peak (Fig 7). The rainfall continued 10 hours, at the same time the precipitation process meets 5 years reoccurrence design tide. So the water logging in urban area was heavier than the process during the super typhoon Rammasun. (Fig8)

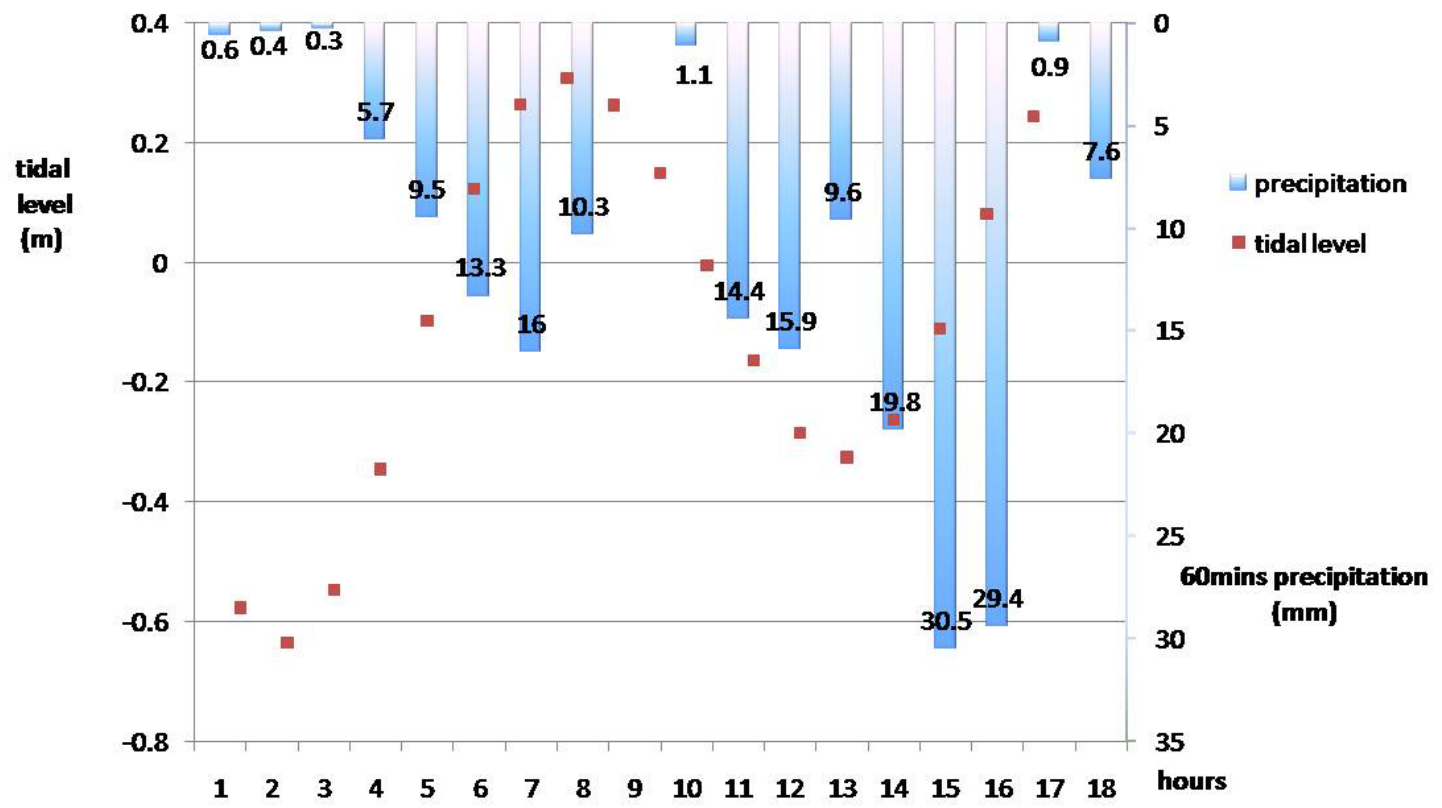

Fig5 Relationship of the precipitation and the tide during Super Typhoon Rammasun 

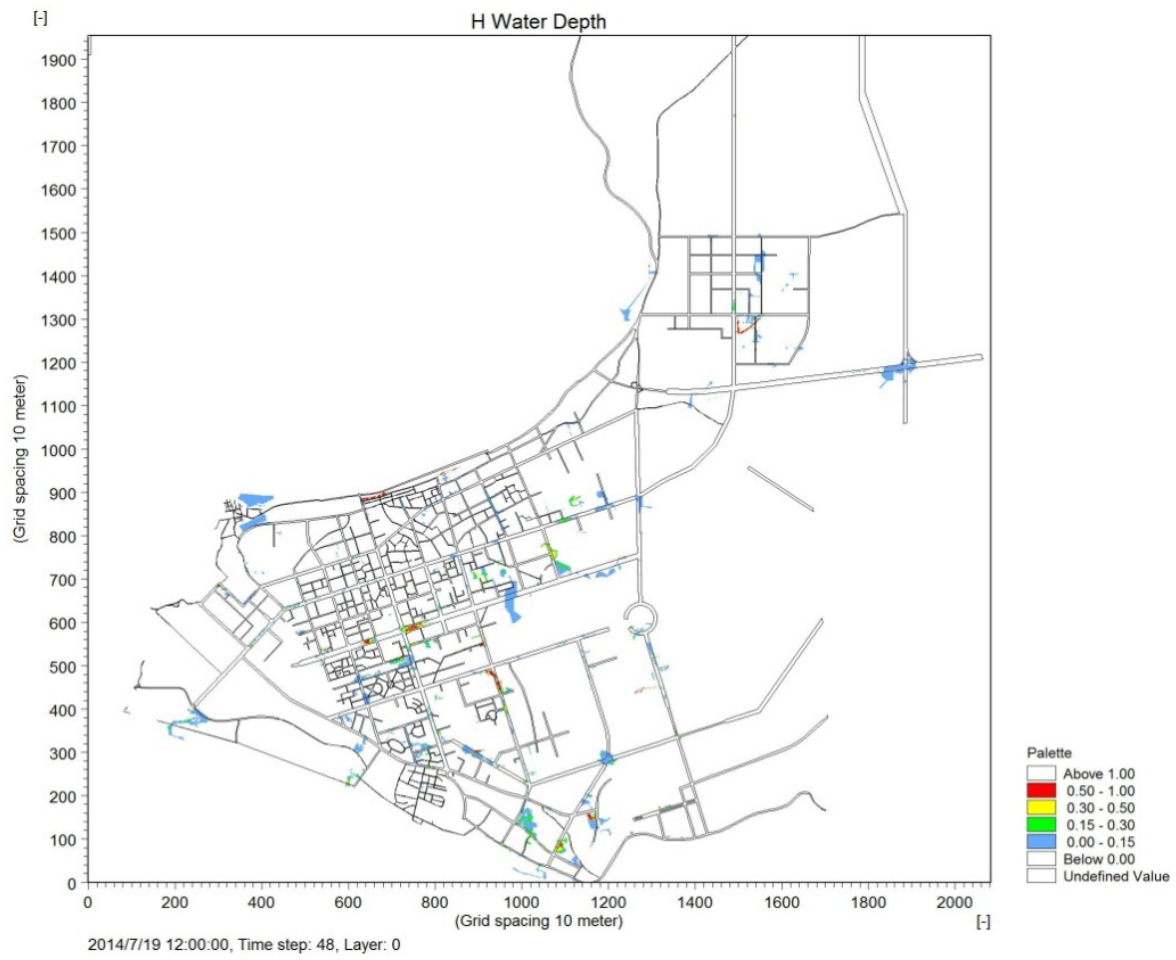

Fig6 Simulate result of Water logging in Beihai urban area during Super Typhoon Rammasun

Table 5. Precipitation with Tidal Level during the process of the super typhoon Rammasun

\begin{tabular}{ccc}
\hline Precipitation interval & Precipitation 60 mins $(\mathrm{mm})$ & Tidal Level (m) \\
\hline 1 & 0.0 & -0.84 \\
2 & 0.0 & -0.64 \\
3 & 0.3 & -0.38 \\
4 & 18.4 & -0.02 \\
5 & 16.2 & 0.42 \\
6 & 3.3 & 0.94 \\
7 & 1.1 & 1.44 \\
8 & 35.8 & 1.85 \\
9 & 47.6 & 2.09 \\
10 & 77.7 & 2.14 \\
11 & 38.5 & 1.97 \\
12 & 2.3 & 1.62 \\
13 & 1.1 & 1.12 \\
14 & 0 & 0.52 \\
15 & 0.1 & -0.11 \\
16 & 0 & -0.67 \\
17 & 0 & -1.11 \\
18 & 0 & -1.37 \\
& & \\
\hline
\end{tabular}




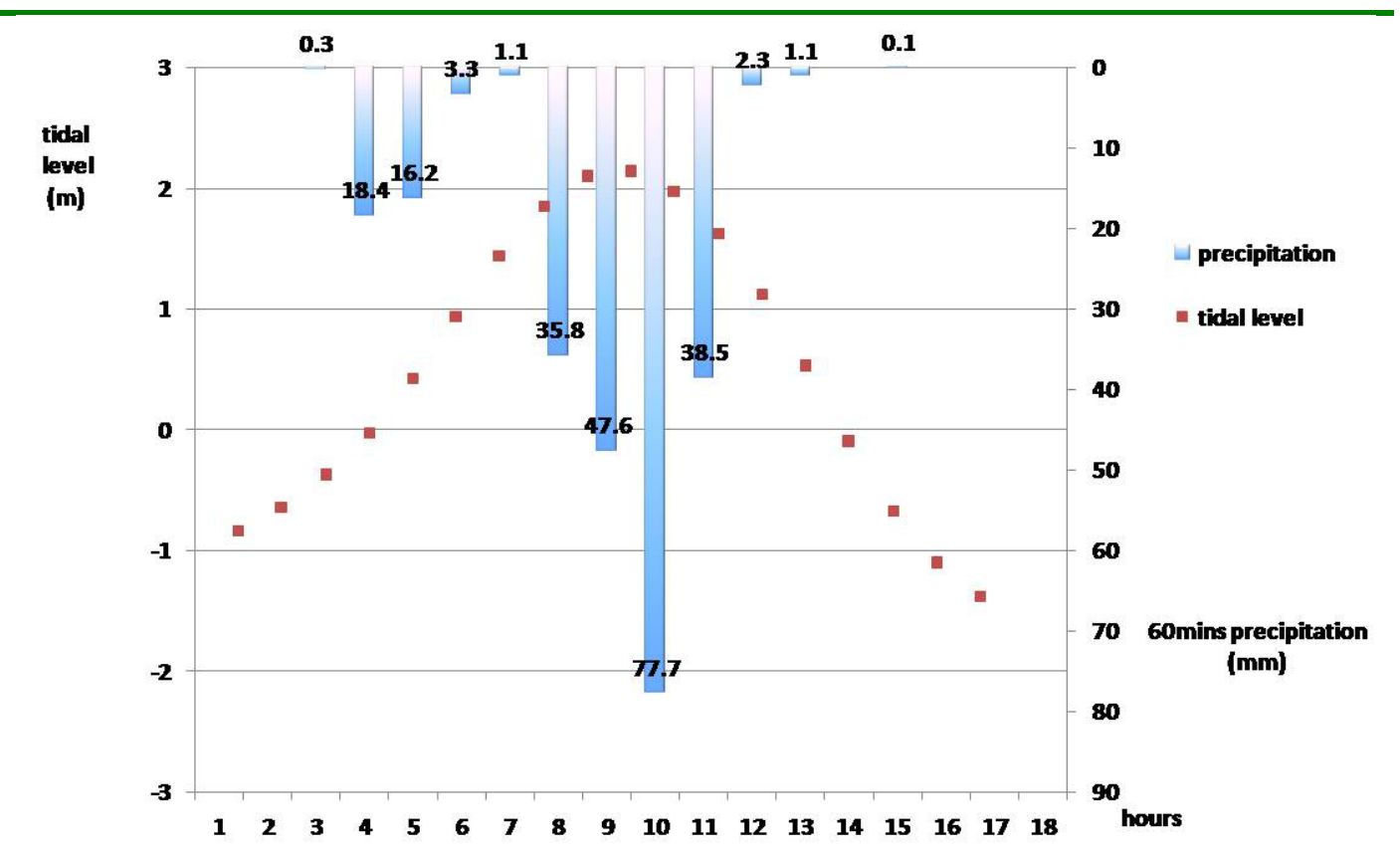

Fig7 Relationship[ of the precipitation and the tide during the hungry ghost festival

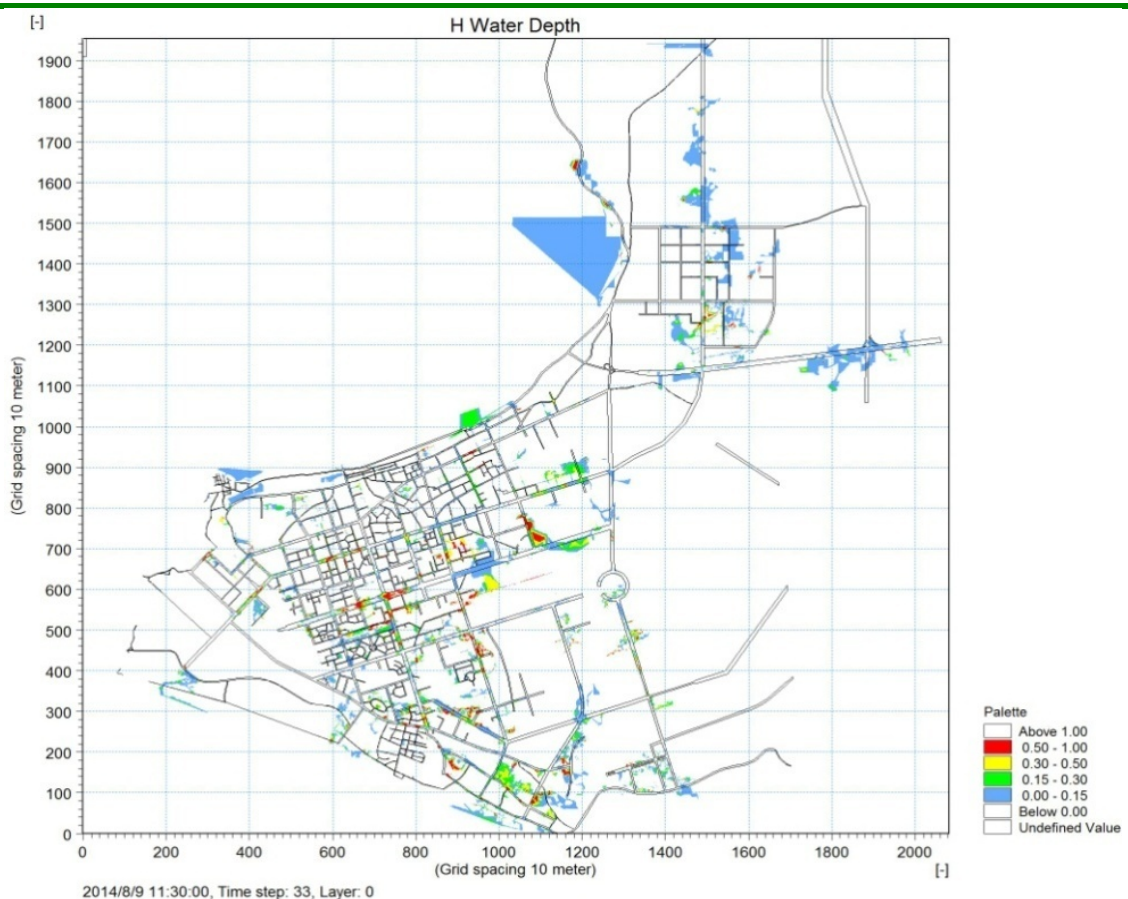

Fig8 Simulate result of Water logging in Beihai urban area during the hungry ghost festival 


\subsection{Simulate results of West-south road of the Beihai city during the hungry ghost festival}

\subsubsection{The Results of design precipitation peak}

According the analysis of the two process which the precipitation meet with the tide, this paper research one zone of the Beihai city in details during the hungry ghost festival (Fig9). The current storm water pipe system in Beihai city and its optimized design plan are simulated. These two urban flood models are set up with the real precipitation process with 5 years reoccurrence tide event and their results are compared. The modeling results of current storm water pipe system in Beihai city show us that lots of areas will not occurrence water logging except several pipes along the
Sichuan Road. Especially, the pipe in the south part of West-south road faced water logging problem heavily than other place. The reason is that the catchment was too large and the outlet for this pipe was far away. Besides, the pipe diameter is too small, which reduced the drainage capacity of this pipe. Because the high water level in urban channel, the flow face the resistance and cannot discharge in the channel rapidly. All of these factors lead to water logging on this road. The catchment of the south part of West-south road suffered urban flooding due to water logging, and the water level of one of the manhole in this pipe reach to $11.5 \mathrm{~m}$. The water logging level on the ground will reach $0.15 \mathrm{~m}$ to $0.6 \mathrm{~m}$ in this road. The water logging will last more than 1 hour (Fig10).
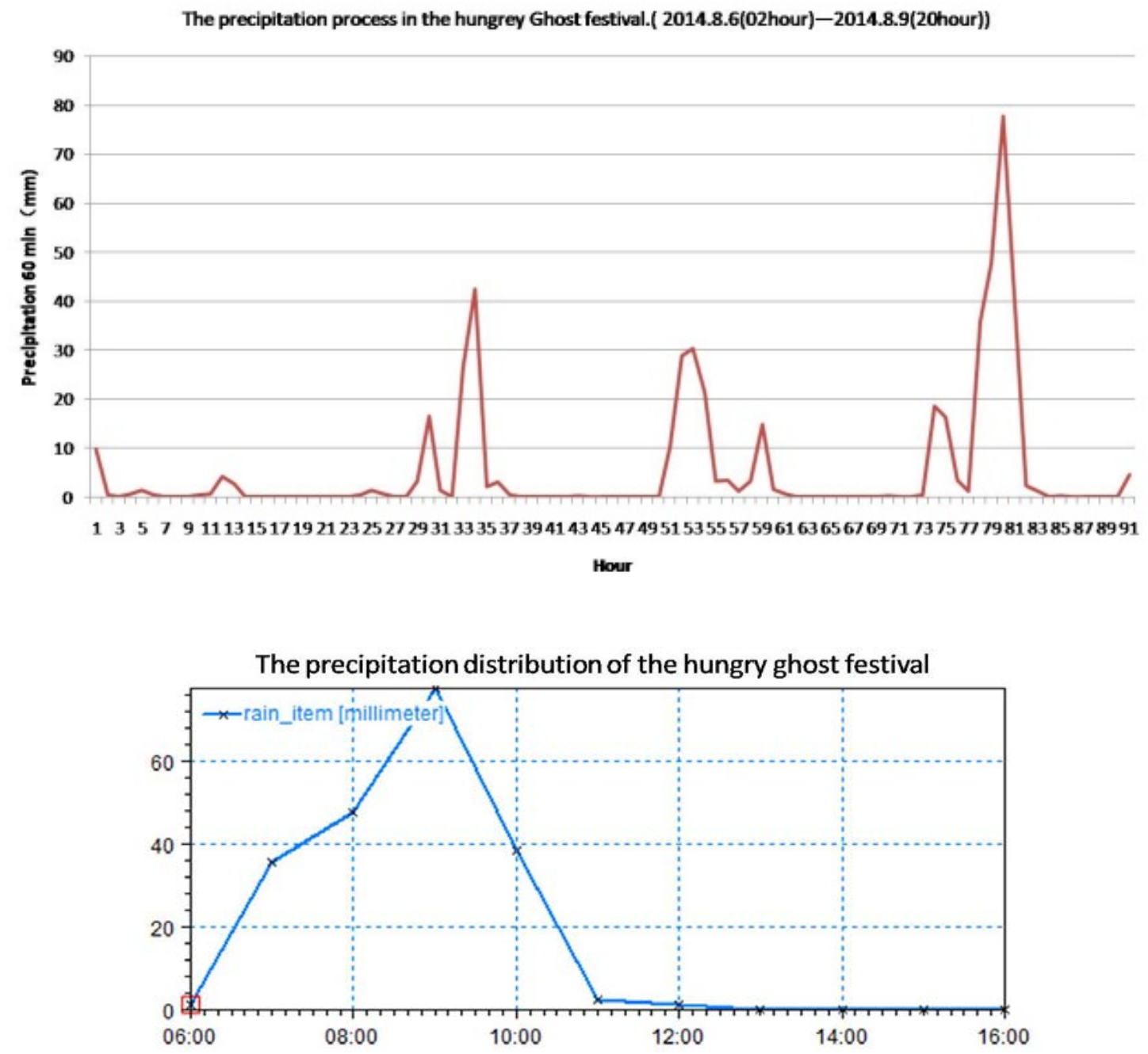

Fig9 Precipitation process during the hungry ghost festival 

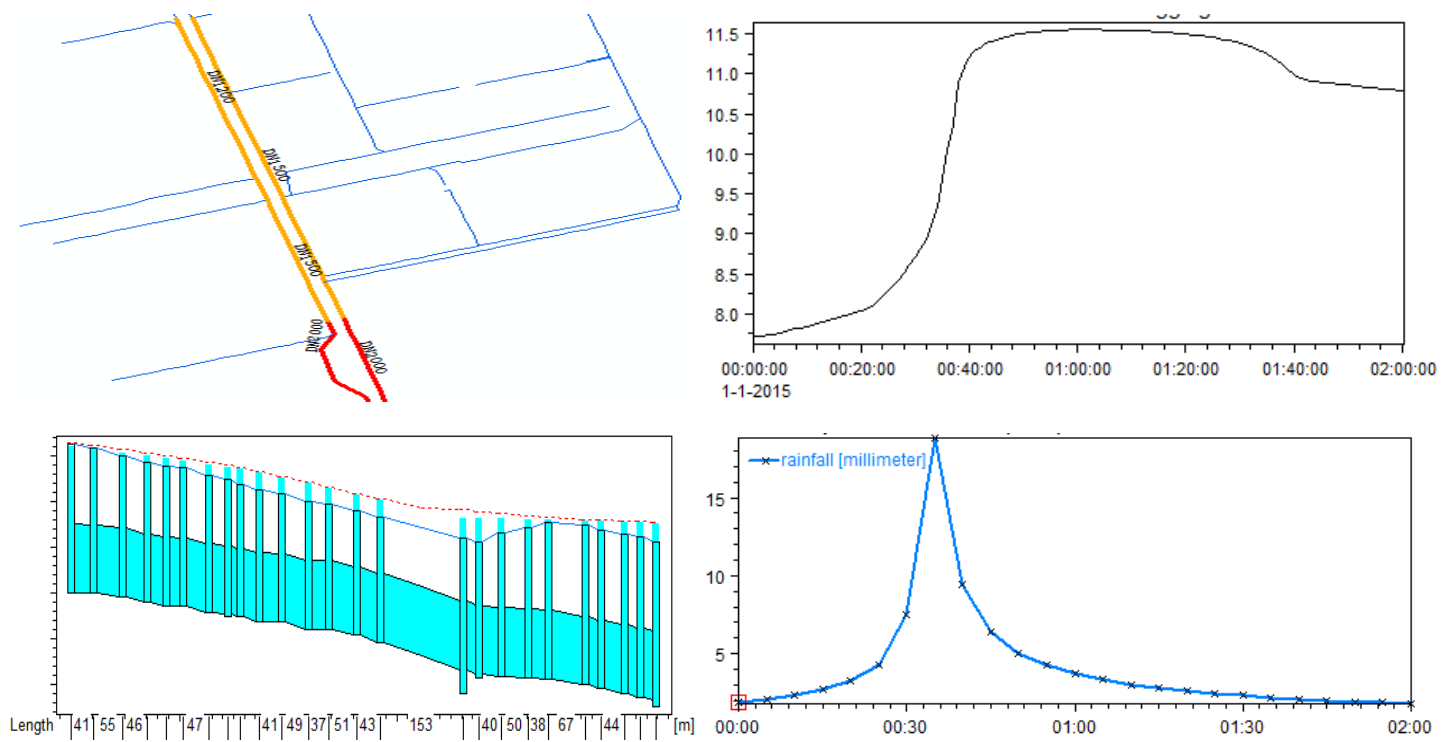

Fig10 Precipitation during the hungry ghost festival with 5 years reoccurrence tidal level of initial plan

In the optimized storm water pipe design plan, an outlet is added at the part of West-south road. The rain water will be drained directly to this outlet rather than its downstream pipe. Besides, the upstream pipe diameter in West-south road is widened from 1.2 meters to 2 meters and the downstream pipe diameter in this road is rebuilt by $4 * 2.5 \mathrm{~m}$ rectangular channel. The performance of this optimized plan proves its advantage compared to the current pipe system. It is well to show that the water logging problem is solved. The modeling results of pipe design plan show that the water level in the same manhole is low to $9.8 \mathrm{~m}$. The water logging does not happen during the simulation (Fig11).
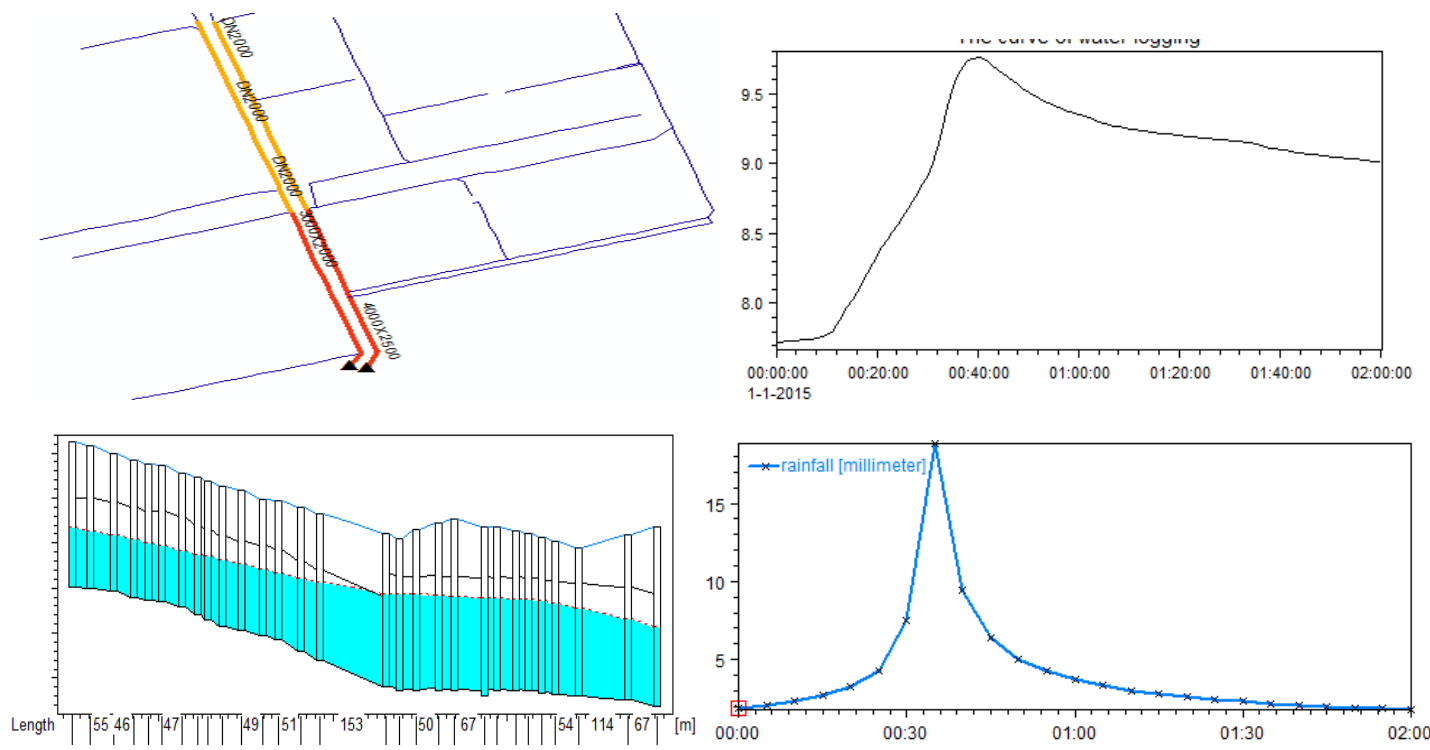

Fig11 Precipitation during the hungry ghost festival with 5 years reoccurrence tidal level of optimized plan 


\section{Conclusions}

A numerical model has been formatted including the ocean, the rain drainage, the urban channels, the brakes, and the pumps by the software MIKE FLOOD which coupling MIKE URBAN, MIKE 11 and MIKE 21. The different scenarios have been simulated. Several conclusions have been drawn as followed:

(1) The precipitation during the super typhoon Rammasun is $185.3 \mathrm{~mm}$, and there were two rainfall peaks, every peak last more than 5 hours. At the same time the precipitation process meets a small tide process. So the water logging in urban area was not heavy. The precipitation during the hungry ghost festival is $242.4 \mathrm{~mm}$, and there were two rainfall peaks, every peak last no more than 4 hours. At the same time the precipitation process meets 5 years reoccurrence design tide. And the whole rainfall process meet with the spring tide process, especially the maximum four hours rainfall meet with the maximum peak. So the water logging in urban area was very heavy.

(2) When the impervious surface is low to $50 \%$ of the land use, the increase rate of the runoff is low to the increase rate of the impervious, but when the impervious surface is up to $50 \%$, the runoff will increase rapidly, and the increase rate is more than the increase rate of the impervious surface. In China, the average impervious surface in the urban area is usually about $55 \%$ to $70 \%$, in the commercial central area, the impervious surface is usually about $75 \%-85 \%$. The impervious surface in Beihai is higher than the average level in China, because the density of the constructs is too high. The impervious surface in the building area of the Sponge City will be below $50 \%$, so the runoff will be reduced $70 \%-80 \%$ by computation of the plan mapping scenario.

(3) Compare two pipe and channel plans, the results show that the water logging of initial plan was heavy, and the water logging level on the ground will reach $0.15 \mathrm{~m}$ to $0.6 \mathrm{~m}$ in this road. The water logging will last more than 1 hour. The modeling results of optimized plan show us that the water level in the same manhole is low to $9.8 \mathrm{~m}$. The water logging does not happen during the simulation.

\section{Acknowledgements}

This paper based on the research is funded by the National Natural Science Foundation of China project Grant Number 51378475.

This paper based on the research is funded by the Beijing Natural Science Foundation project Grant Number8132046.

This paper based on the research is funded by The major projects of national water pollution control

Grant Number2013ZX07304-001.

\section{References}

BerislavTomic and Ole Mark (2004).Urban flooding modelling study at playa de gandia. In: Urban Drainage Modelling - A Collection of Experiences from the Past Decade, 2nd edn, Scand-Media, Thailand, pp.85-100

Bo-Huang, Shujuan-Zhou, Feng-Yuan, Jing-Ge, Fei-Peng (2010).Flood Risk Management in the Deltas of Yellow River, Rhine River and Mississippi River, Yellow River Conservancy Press, China, pp.19-23, 124-137

ChusitApirumanekul and Ole Mark (2004).Modelling of urban flooding in Dhaka city. In: Urban Drainage Modelling - A Collection of Experiences from the Past Decade, 2nd edn,Scand-Media, Thailand, pp.101-108

Hongtao Ma, Xiaoxin Zhang, Qiang Wang (2008). The Urban Rain Drainage System Plan and Optimization Based on the Modelling in Olympic Garden in Beijing. Water and Wastewater, 34(10),

Jun Liu (2006). Modelling of Drainage and Water Logging of Shanghai Urban Based on SWMM. China Water and Wastewater, 22(21),

Jonathan Parkinson and Ole Mark (2004).Urban Stormwater Management in Developing Countries.IWA Publishing, London, UK.

Sicheng Zhu, Xiyan Ren (2011). The Research of Urban Water Logging. Administrative management reform, 11, 62-66.

Xiaotao Cheng (2009).Urban Flood Prediction and Its Risk Analysis in the Castal Areas of China. China Water Power Press, China, pp.16-42, 54-101, 164-244

Yue Zhang (2010). The Strategy to Urban Storm Water Logging. China Water and Wastewater, 16, 42-47. 